\title{
Pacific fisheries meet 'fails to end tuna overfishing'
}

\section{Conservation body accused of failing to take responsibilities seriously.}

\section{Prime Sarmiento}

11 December 2012

\section{MANILA}

\section{An article by SciDev.Net.}

A five-day meeting on fisheries ended last week (6 December) amid complaints that big fishing nations have blocked efforts to curb tuna overfishing and ignored scientific advice.

The accusations were made following the ninth regular session of the Western and Central Pacific Fisheries Commission, which is the governing body for an international fisheries agreement that seeks to ensure the conservation and sustainable use of highly migratory fish, such as tuna, in parts of the Pacific Ocean.

Nanette Malsol, chair of the Parties to the Nauru Agreement (PNA), a management body

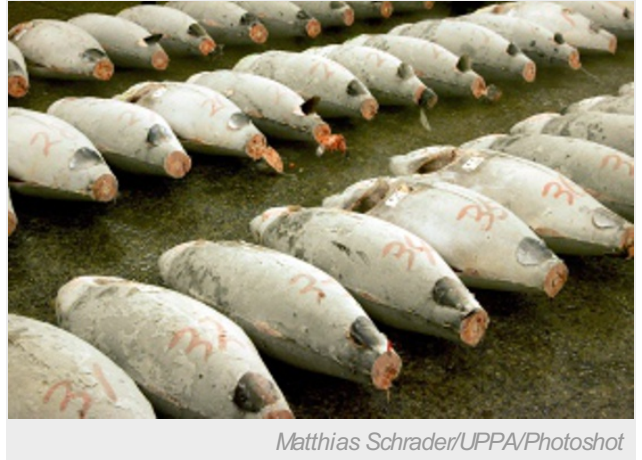

Growing consumer demand is hitting tuna stocks. for sustainable fisheries that represents eight nations in the Oceania region, said the commission had "failed to take its responsibilities seriously regarding the fate of tuna".

The PNA had called for a stop to the overfishing of bigeye tuna, an important food fish.

Speaking to SciDev.Net, Gerry Leape, the head of the US-based Pew Environment Group's delegation, added: "The commission has ignored the scientific advice that we need to stop overfishing and chose instead to protect its individual interests".

Leape was disappointed that delegates preferred to discuss "how much overfishing to allow, rather than how to end it". Unless overfishing in the tropical seas can be controlled, global tuna stocks will continue to decline, he said.

Malsol said: "The big fishing nations did not make any significant commitments to cut their overfishing of bigeye tuna. It is the big fishing nations of the EU, and the US and Japan that have historically overfished this tuna," noting that the bigeye is fished at 40 per cent above the sustainable level.

Other members such as Taiwan and South Korea agreed to voluntarily cut their longline catch by ten per cent and two per cent respectively, she said. But this is way below the 30 per cent reduction in the total catch by all methods that the PNA and conservation groups were calling on every country to make. 
being taken from the western and central Pacific regions, according to Pew. Japan catches and eats more tuna than any other nation, it said.

But overfishing due to growing consumer demand and harmful fishing practices have depleted tuna stocks, according to Pew. The International Union for Conservation of Nature has put yellowfin and albacore tuna in the "near threatened" category and classified bigeye as "vulnerable".

Despite the disappointment over the lack of significant steps to tackle overfishing, Malsol welcomed the commission's decision to tighten controls on illegal fishing and to ban the setting of fishing nets around whale sharks.

\section{SciDev Net}

Read more at SciDev.Net
The commission also agreed to further limit the use of floating "fish aggregating devices" (FADs) that lure fish to make it easier for ships to haul them in. The period during which these are banned will rise from three to four months of the year. Pew estimates that 47,000 to 105,000 of these devices are put into the world's oceans every year.

Adam Baske, Pew's tuna campaign manager, said the 'purse seine' nets that are used to catch fish attracted by the FADs capture everything around the devices, accidentally killing juvenile tuna and other marine animals such as sharks, stingrays and turtles. The devices are also becoming a marine nuisance, with debris ending up in coral reefs, he said.

Nature | doi:10.1038/nature.2012.12019

This article was originally published by SciDev.Net on 10 December 2012.

\section{SPRINGER NATURE}

